\title{
Synthesis and Structural Studies of a New Complex of Di[hexabromobismuthate (III)] 2,5-Propylaminepyrazinium $\left[\mathrm{C}_{10} \mathrm{H}_{28} \mathrm{~N}_{4}\right] \mathrm{Bi}_{2} \mathrm{Br}_{10}$
}

\author{
Mohamed El Mehdi Touati and Habib Boughzala \\ Laboratoire de Matériaux et Cristallochimie, Faculté des Sciences, Université de Tunis El Manar, 2092 Tunis, Tunisia \\ Correspondence should be addressed to Habib Boughzala; boughzala@yahoo.com
}

Received 29 September 2014; Revised 15 December 2014; Accepted 20 December 2014

Academic Editor: Jolanta N. Latosinska

Copyright (C) 2015 M. E. M. Touati and H. Boughzala. This is an open access article distributed under the Creative Commons Attribution License, which permits unrestricted use, distribution, and reproduction in any medium, provided the original work is properly cited.

\begin{abstract}
A new organic-inorganic hybrid material, $\left[\mathrm{C}_{10} \mathrm{H}_{28} \mathrm{~N}_{4}\right] \mathrm{Bi}_{2} \mathrm{Br}_{10}$, has been synthesized and characterized. The compound crystallizes in monoclinic $\mathrm{P} 21 /$ c space group with $a=11.410$ (4) $\AA, b=11.284(4) \AA, c=12.599(3) \AA, \beta=115.93(2)^{\circ}$, and $V=1458.8(8) \AA^{3}$. The structure consists of discrete dinuclear $\left[\mathrm{Bi}_{2} \mathrm{Br}_{10}\right]^{4-}$ anions and $\left[\mathrm{C}_{10} \mathrm{H}_{28} \mathrm{~N}_{4}\right]^{4+}$ cations. It consists of a 0 -D anion built up of edge-sharing bioctahedron. The crystal net contains $\mathrm{N}-\mathrm{H} \cdots \mathrm{Br}$ hydrogen bonds. The differential scanning calorimetry (DSC) reveals an irreversible phase transition at $-17^{\circ} \mathrm{C}$. The frontier molecular orbital and the energy gap between the highest occupied molecular orbital (HOMO) and the lowest unoccupied molecular orbital (LUMO) calculation allow the classification of the material as an insulator.
\end{abstract}

\section{Introduction}

The results of systematic structural investigations of halobismuthate (III) compounds reveal a great variety of different anionic frameworks. Most of these compounds are described by a general formula $\mathrm{R}^{+a}\left(\mathrm{M}_{b} \mathrm{X}_{3 b+a}\right)^{-a}$ (where $\mathrm{R}$ is organic cations, $\mathrm{M}$ is $\mathrm{Bi}$, and $\mathrm{X}$ is $\mathrm{Cl}, \mathrm{Br}$, and I) and have a tendency to constitute bi- or polynuclear anions in the crystalline state.

Generally, in these compounds, the coordination sphere of bismuth appears to be dominated by the tendency towards hexacoordination with polybismuthate species arising from corner, edges, or faces sharing $\mathrm{BiX}_{6}$ distorted octahedra.

The formation of the anionic sublattice is clearly determined by the counteractions, but the effects of their most evident properties such as charge, size, and shape are almost not predictable. The organic moiety can be used as physical and electronic barrier, contributing to original electrical and optical behaviour. In addition, since, in the crystal state, important contribution to the lattice stabilization is due to hydrogen bonding interactions, it should be possible to influence the bismuth coordination geometry acting on the number and orientation of the hydrogen bond donor sites of the cations [1-4].

\section{Synthesis Experimental Protocol}

The title compound was synthesized by dissolving stoichiometric amounts of bismuth (III) bromide in piperazine in a mixture of water and $\mathrm{HBr}$. The resulting solution was stirred well and then kept at room temperature. Few weeks later, transparent crystals, as bright-yellow prism, were grown by slow evaporation. The purity of synthesized compound was improved by successive recrystallization process.

\section{Results and Discussion}

3.1. X-Ray Data Collection. The X-ray diffraction intensities from a single crystal of about $(0.3 \times 0.3 \times 0.1) \mathrm{mm}^{3}$ were collected with a CAD-4 (Enraf Nonius) diffractometer using the Mo $K \alpha$ radiation $(\lambda=0.71073 \AA)$. The crystal structure was solved by direct methods using SHELXS-97 [5]. Full-matrix $F^{2}$ least-squares refinement and subsequent Fourier synthesis procedures were performed using SHELXL-97 [6]. Molecular graphics were prepared using Diamond 3 [7]. CCDC1008226 contains the supplementary crystallographic data for this compound. These data can be obtained free of charge at http://www.ccdc.cam.ac.uk/conts/retrieving.html or from 
TABLE 1: Experimental data for $\mathrm{C}_{10} \mathrm{H}_{28} \mathrm{~N}_{4} \mathrm{Bi}_{2} \mathrm{Br}_{10}$.

\begin{tabular}{|c|c|c|c|}
\hline \multicolumn{2}{|c|}{ Crystal data } & \multicolumn{2}{|c|}{ Data collection } \\
\hline Empirical formula & $\mathrm{C}_{10} \mathrm{H}_{28} \mathrm{~N}_{4} \mathrm{Bi}_{2} \mathrm{Br}_{10}$ & Diffractometer & Enraf-Nonius CAD-4 \\
\hline Formula weight & $1417.42\left(\mathrm{~g} \cdot \mathrm{mol}^{-1}\right)$ & Wavelength: $\lambda$ & $0.71073 \AA$ \\
\hline Crystal system & Monoclinic & $\theta$ range & $2.55^{\circ} \leq \theta \leq 26.97^{\circ}$ \\
\hline Space group & $\mathrm{P} 22_{1} / \mathrm{c}$ & Temperature & $298(2) \mathrm{K}$ \\
\hline Unit cell dimensions & $\begin{array}{c}a=11.410(4) \AA \\
b=11.284(4) \AA \\
c=12.599(3) \AA \\
\beta=115.93(2)^{\circ}\end{array}$ & Limiting indices $h, k$, and $l$ & $\begin{array}{c}-14 \leq h \leq 13 \\
0 \leq k \leq 14 \\
0 \leq l \leq 16\end{array}$ \\
\hline Crystal habit & Yellow prism & Absorption correction & Psi scan \\
\hline Volume & $V=1458.8(8) \AA^{3}$ & Standard reflection & 2 every $120 \mathrm{~min}$ \\
\hline$Z$ & $Z=4$ & Measured reflections & 3697 \\
\hline Absorption coefficient & $\mu=25.75 \mathrm{~mm}^{-1}$ & Independent reflections & 3177 \\
\hline$F(000)$ & 1264 & Observed reflections $I>2 \sigma(I)$ & 2352 \\
\hline Crystal size $\left(\mathrm{mm}^{3}\right)$ & $(0.3 \times 0.3 \times 0.1)$ & $\mathrm{R}_{\text {int }}$ & 0.062 \\
\hline Density $_{\text {calc }}$ & $D_{\text {calc }}=3.236$ & $T_{\min } / T_{\max }$ & $0.001 / 0.074$ \\
\hline \multicolumn{4}{|c|}{ Refinement } \\
\hline Refinement & Least square on $F^{2}$ & $\Delta \rho_{\max }$ & $4.95 \mathrm{e}^{-3}$ \\
\hline $\mathrm{R}\left[F^{2}>2 \sigma\left(F^{2}\right)\right]$ & 0.066 & $\Delta \rho_{\min }$ & $-7,09 \mathrm{e} \AA^{-3}$ \\
\hline$S$ & 1.06 & wR & 0.169 \\
\hline
\end{tabular}

the Cambridge Crystallographic Data Centre (CCDC), 12 Union Road, Cambridge CB2 1EZ, UK.

Hydrogen atoms were located at their idealized positions using appropriate HFIX instructions in SHELXL-97 and included in subsequent least-squares refinement cycles in riding-motion approximation. Crystal data and parameters of the final refinement are reported in Table 1.

3.2. Crystal Morphology. Crystal morphology is a key element in many industrial processes and has an enormous impact in the materials processing stages. Thus, rationalization of the relationships between crystal morphology and the arrangement of atoms in the bulk crystal lattice is of great interest in many areas of science.

The crystal morphology prediction was obtained by BFDH (Bravais-Fridel and Donnay-Harker) [8-10] algorithm calculation using Mercury (CSD 3.0.1) [11].

The program uses the crystal lattice parameters and the symmetry space group to generate a list of possible growth faces and their relative growth rates.

The qualitative analysis result obtained by energy dispersive X-ray spectroscopy (EDX) is presented in Figure 1. It reveals the presence of the chemical elements identified by the single crystal X-ray diffraction.

The scanning electron microscopy with energy dispersive $\mathrm{X}$-ray spectroscopy (SEM/EDX) high resolution images of the surface topography produces an image of the focused crystal. The view of the observed and calculated crystal morphologies reveals a similarity between the two shapes (Figure 2). This result allows identifying the crystallographic axis and shows the absence of preferential orientation of crystallites.

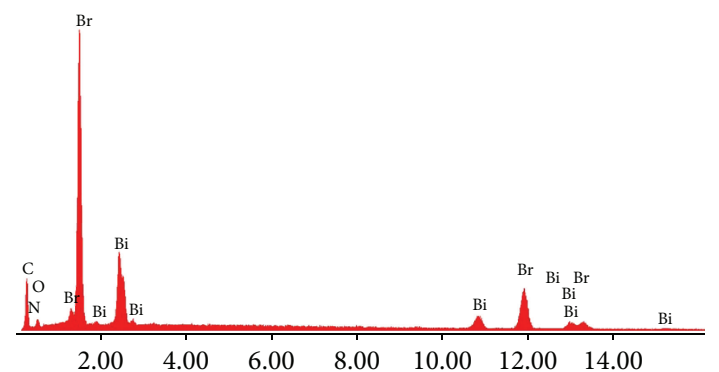

Figure 1: Qualitative analysis by EDX of $\mathrm{C}_{10} \mathrm{H}_{28} \mathrm{~N}_{4} \mathrm{Bi}_{2} \mathrm{Br}_{10}$.

3.3. Structure Description. At room temperature, the present compound crystallizes in the monoclinic $\mathrm{P} 22_{1} / \mathrm{c}$ space group. The asymmetric unit contains two bromobismuthate $\left[\mathrm{Bi}_{2} \mathrm{Br}_{10}\right]^{4-}$ anions and $\left[\mathrm{C}_{10} \mathrm{H}_{28} \mathrm{~N}_{4}\right]^{4+}$ cation, as shown in Figure 3.

The organic and inorganic moieties are linked by $\mathrm{N}-$ $\mathrm{H}$... Br hydrogen bonds ensuring the structure cohesion.

The 1:5 stoichiometry of anionic part $\left[\mathrm{Bi}_{2} \mathrm{Br}_{10}\right]^{4-}$ can be realized by different types of anionic sublattices.

In this compound, two $\mathrm{BiBr}_{6}$ octahedra share two bridging $\mathrm{Br}$ atoms and consequently form dinuclear $\left[\mathrm{Bi}_{2} \mathrm{Br}_{10}\right]^{4-}$ anion. One bismuth (III) ion is surrounded by six bromine anions; however, $\mathrm{Bi}-\mathrm{Br}$ distances fall into two ranges: $2.793(2)$ to 2.894(2) A for terminal Br and 2.981(4) to 3.079(2) $\AA$ for the bridging ones (Table 2). Lower than the sum of Van der Waals radii (4.35 $\AA$ according Pauling [12]), we deduce that the bismuth-bromine bonds have a dominant covalent character. 


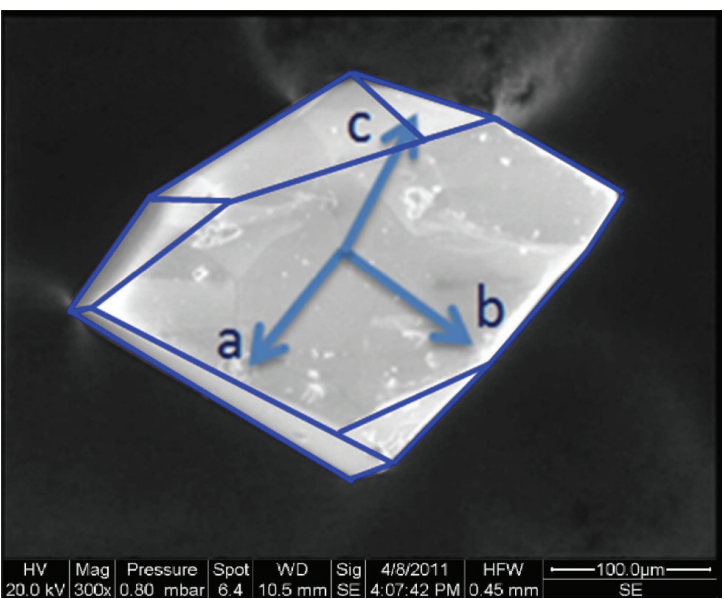

(a)

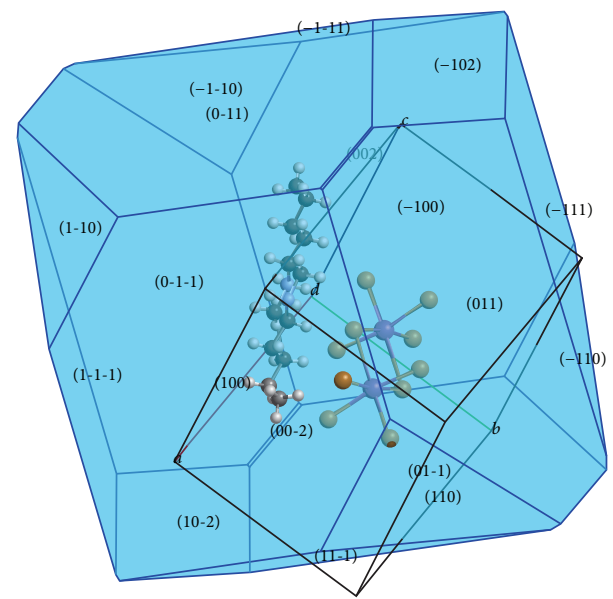

(b)

FIGURE 2: Observed and calculated morphologies of $\mathrm{C}_{10} \mathrm{H}_{28} \mathrm{~N}_{4} \mathrm{Bi}_{2} \mathrm{Br}_{10}$ crystals.

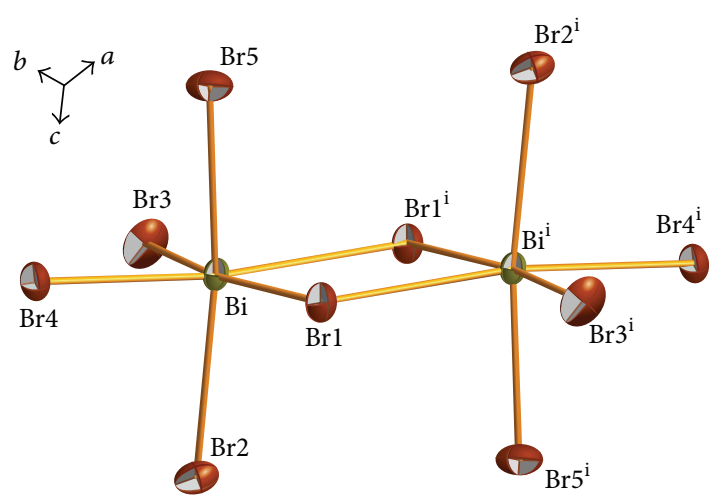

(a)

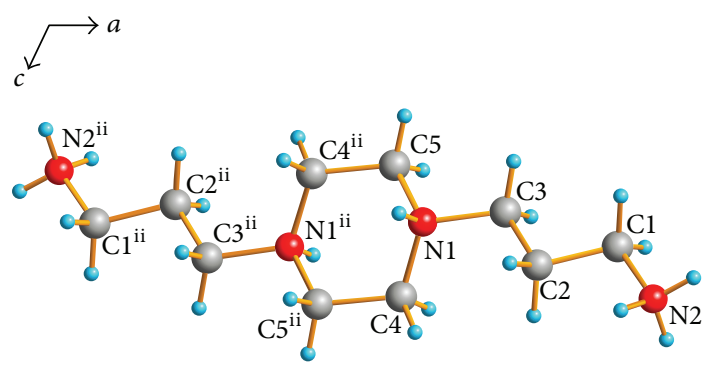

Symmetry codes: (i) $-x+1,-y,-z+2$; (ii) $-x+1,-y,-z+1$

(b)

FIGURE 3: ORTEP of the inorganic part $\left[\mathrm{Bi}_{2} \mathrm{Br}_{10}\right]^{4-}$ in (a) and the organic moiety $\left[\mathrm{C}_{10} \mathrm{H}_{28} \mathrm{~N}_{4}\right]^{4+}$ in (b) with $50 \%$ of probability level.

The $\mathrm{BiBr}_{6}$ octahedra are somewhat distorted. As described by Shannon [13], the distortion index of this polyhedra $\left(\mathrm{ID}_{(\mathrm{Bi}-\mathrm{Br})}=1.8810^{-3}\right)$ indicates a significant dissymmetry in the dinuclear entity $\left[\mathrm{Bi}_{2} \mathrm{Br}_{10}\right]^{4-}$

$$
\text { With ID }(\mathrm{Bi}-\mathrm{Br})=\frac{1}{6} \sum_{i=1}^{6}\left(\frac{(\mathrm{BiBr})_{i}-(\mathrm{BiBr})_{m}}{(\mathrm{BiBr})_{m}}\right)^{2} \text {, }
$$

TABLE 2: Selected interatomic distances $(\AA)$ and angles $\left(^{\circ}\right)$ in the structure of $\mathrm{C}_{10} \mathrm{H}_{28} \mathrm{~N}_{4} \mathrm{Bi}_{2} \mathrm{Br}_{10}$.

(a) Octahedra $\mathrm{BiBr}_{6}$

\begin{tabular}{lccc}
\hline $\mathrm{Bi}-\mathrm{Br} 4$ & $2.744(2)$ & $\mathrm{Br} 5-\mathrm{Bi}-\mathrm{Br} 2$ & $169.15(6)$ \\
$\mathrm{Bi}-\mathrm{Br} 3$ & $2.748(3)$ & $\mathrm{Br} 4-\mathrm{Bi}-\mathrm{Br} 1$ & $98.30(6)$ \\
$\mathrm{Bi}-\mathrm{Br} 5$ & $2.793(2)$ & $\mathrm{Br} 3-\mathrm{Bi}-\mathrm{Br} 1$ & $170.84(6)$ \\
$\mathrm{Bi}-\mathrm{Br} 2$ & $2.894(2)$ & $\mathrm{Br} 5-\mathrm{Bi}-\mathrm{Br} 1$ & $84.48(7)$ \\
$\mathrm{Bi}-\mathrm{Br} 1$ & $2.981(4)$ & $\mathrm{Br} 2-\mathrm{Bi}-\mathrm{Br} 1$ & $91.96(6)$ \\
$\mathrm{Bi}-\mathrm{Brl}{ }^{\mathrm{i}}$ & $3.079(2)$ & $\mathrm{Br} 4-\mathrm{Bi}-\mathrm{Brl}{ }^{\mathrm{i}}$ & $170.99(5)$ \\
$\mathrm{Br}^{\mathrm{B}}-\mathrm{Bi}$ & $3.079(2)$ & $\mathrm{Br} 3-\mathrm{Bi}-\mathrm{Brl}{ }^{\mathrm{i}}$ & $82.72(6)$ \\
$\mathrm{Br} 4-\mathrm{Bi}-\mathrm{Br} 3$ & $90.61(7)$ & $\mathrm{Br} 5-\mathrm{Bi}-\mathrm{Brl}{ }^{\mathrm{i}}$ & $90.14(6)$ \\
$\mathrm{Br} 4-\mathrm{Bi}-\mathrm{Br} 5$ & $84.30(6)$ & $\mathrm{Br} 2-\mathrm{Bi}-\mathrm{Brl}{ }^{\mathrm{i}}$ & $100.00(6)$ \\
$\mathrm{Br} 3-\mathrm{Bi}-\mathrm{Br} 5$ & $94.36(7)$ & $\mathrm{Br} 1-\mathrm{Bi}-\mathrm{Br} 1^{\mathrm{i}}$ & $88.19(5)$ \\
$\mathrm{Br} 4-\mathrm{Bi}-\mathrm{Br} 2$ & $86.09(6)$ & $\mathrm{Bi}-\mathrm{Br} 1-\mathrm{Bi}$ & $91.81(5)$ \\
$\mathrm{Br} 3-\mathrm{Bi}-\mathrm{Br} 2$ & $90.75(7)$ & & \\
\hline
\end{tabular}

(b) Organic group

\begin{tabular}{|c|c|c|c|}
\hline $\mathrm{C} 1-\mathrm{N} 2$ & $1.490(2)$ & N2-C1-C2 & $111.30(1)$ \\
\hline $\mathrm{C} 1-\mathrm{C} 2$ & $1.500(2)$ & $\mathrm{C} 1-\mathrm{C} 2-\mathrm{C} 3$ & $109.00(1)$ \\
\hline $\mathrm{C} 2-\mathrm{C} 3$ & $1.500(2)$ & $\mathrm{C} 2-\mathrm{C} 3-\mathrm{N} 1$ & $113.30(1)$ \\
\hline $\mathrm{C} 3-\mathrm{N} 1$ & $1.501(2)$ & $\mathrm{N} 1-\mathrm{C} 4-\mathrm{C} 5^{\mathrm{ii}}$ & $113.60(1)$ \\
\hline $\mathrm{C} 4-\mathrm{N} 1$ & $1.454(2)$ & $\mathrm{N} 1-\mathrm{C} 5-\mathrm{C} 4^{\mathrm{ii}}$ & $112.50(1)$ \\
\hline $\mathrm{C} 4-\mathrm{C} 5^{\mathrm{ii}}$ & $1.520(2)$ & C4-N1-C3 & 115.10 (1) \\
\hline C5-N1 & $1.510(2)$ & C4-N1-C5 & 110.00 (1) \\
\hline $\mathrm{C} 5-\mathrm{C} 4^{\mathrm{ii}}$ & $1.520(2)$ & C3-N1-C5 & $109.50(1)$ \\
\hline
\end{tabular}

Symmetry codes: (i) $-x+1,-y,-z+2$; (ii) $-x+1,-y, z+1$.

where $(\mathrm{BiBr})_{m}$ is the average value of the $\mathrm{Bi}-\mathrm{Br}$ bond length. The bond angles values (see Table 3) confirm the octahedral distortion since they are, in some cases, $10^{\circ}$ less than the ideal values.

The intermolecular $\mathrm{N}-\mathrm{H} \cdots \mathrm{Br}$ hydrogen bonds can be also the reason of geometrical distortion of $\left[\mathrm{Bi}_{2} \mathrm{Br}_{10}\right]^{4-}$ anion, due to possibility of shifting of the halogen atoms in the direction of the positive charge located on the cations. 
TABLE 3: Hydrogen bonds for $\mathrm{C}_{10} \mathrm{H}_{28} \mathrm{~N}_{4} \mathrm{Bi}_{2} \mathrm{Br}_{10}$ (D: donor; A: acceptor).

\begin{tabular}{lcccc}
\hline $\mathrm{D}-\mathrm{H} \cdots \mathrm{A}$ & $\mathrm{D}-\mathrm{H}(\AA)$ & $\mathrm{H} \cdots \mathrm{A}(\AA)$ & $\mathrm{D} \cdots \mathrm{A}(\AA)$ & $\mathrm{D}-\mathrm{H} \cdots \mathrm{A}\left({ }^{\circ}\right)$ \\
\hline $\mathrm{N} 1-\mathrm{H} 1 \cdots \mathrm{Br} 5$ & 0.909 & $2.779(3)$ & $3.534(1)$ & $141.27(7)$ \\
$\mathrm{N} 2-\mathrm{HA} \cdots \mathrm{Br} 3$ & 0.890 & $2.703(2)$ & $3.537(2)$ & $156.38(1)$ \\
$\mathrm{N} 2-\mathrm{HB} \cdots \mathrm{Br} 2$ & 0.890 & $2.792(2)$ & $3.521(2)$ & $149.03(1)$ \\
$\mathrm{N} 2-\mathrm{HB} \cdots \mathrm{Br} 4$ & 0.890 & $2.829(2)$ & $3.487(2)$ & $131.92(1)$ \\
\hline
\end{tabular}

TABLE 4: Infrared bands observed and assigned to vibration modes for $\mathrm{C}_{10} \mathrm{H}_{28} \mathrm{~N}_{4} \mathrm{Bi}_{2} \mathrm{Br}_{10}$.

\begin{tabular}{lc}
\hline Observed frequencies $\left(\mathrm{cm}^{-1}\right)$ & Attributions \\
\hline 3470 & Stretching $(\mathrm{N}-\mathrm{H})$ \\
2925 & Stretching $(\mathrm{C}-\mathrm{H})$ \\
1640 & Bending $(\mathrm{N}-\mathrm{H})$ \\
1389 & Bending $(\mathrm{C}-\mathrm{H})$ and stretching $(\mathrm{C}-\mathrm{C})$ \\
1114 & Stretching $(\mathrm{C}-\mathrm{N})$ \\
\hline
\end{tabular}

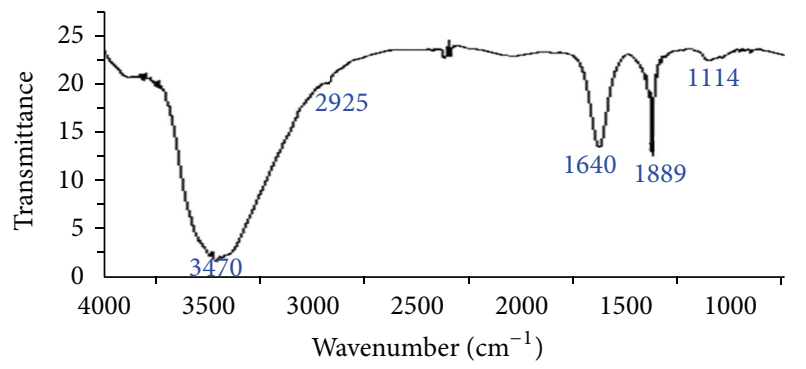

Figure 4: Observed IR spectrum of the compound $\mathrm{C}_{10} \mathrm{H}_{28} \mathrm{~N}_{4} \mathrm{Bi}_{2} \mathrm{Br}_{10}$.

The protonation of $\left[\mathrm{C}_{10} \mathrm{H}_{28} \mathrm{~N}_{4}\right]$ leads to $\left[\mathrm{C}_{10} \mathrm{H}_{28} \mathrm{~N}_{4}\right]^{4+}$. These cations are stacked between the planes containing the bioctahedrons $\left[\mathrm{Bi}_{2} \mathrm{Br}_{10}\right]^{4-}$.

Each bioctahedron is sandwiched between two sheets of organic cations, setting out its 6 vertices $\mathrm{Br}^{-}$where three links to the higher plane and the others with the lower one by hydrogen bonds involve the terminal amino group of the organic cations.

Hydrogen bonds are linking the organic and inorganic moieties (Table 3). This fact can explain the observed fragility of the crystals. The hydrogen bonds ensure the crystal cohesion by connecting the alternating organic-inorganic layers and building a three-dimensional framework.

3.4. Infrared Spectroscopy. The IR spectrum of $\mathrm{C}_{10} \mathrm{H}_{28} \mathrm{~N}_{4} \mathrm{Bi}_{2} \mathrm{Br}_{10}$ (Figure 4 and Table 4) was recorded at room temperature in the range of 400 to $4000 \mathrm{~cm}^{-1}$ using the VERTEX $80 / 80 \mathrm{v}$ FT-IR research spectrometer, by dispersing $2 \%$ of the studied compound in $\mathrm{KBr}$ discs. We have calculated the vibrational spectrum by using semiempirical PM3 geometry optimization by "CAChe" program [14].

After an optimization of the molecular configuration, the calculated spectrum, presented in Figure 5, is very helpful for the attribution of the observed spectroscopic bands. On

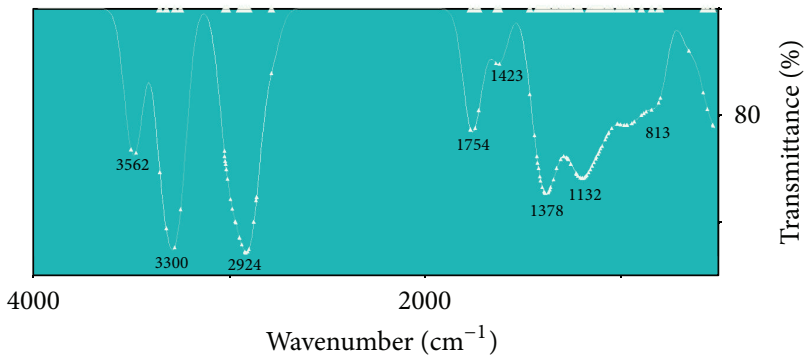

FIGURE 5: Calculated IR spectrum of the compound $\mathrm{C}_{10} \mathrm{H}_{28} \mathrm{~N}_{4} \mathrm{Bi}_{2} \mathrm{Br}_{10}$.

the other hand, the observed bands assignment becomes easier by comparing the observed frequencies and those calculated.

Based on the previous literature results and the theoretical simulation of the IR spectrum, the large band around $3470 \mathrm{~cm}^{-1}$ is attributed to the stretching modes of $(\mathrm{N}-\mathrm{H})$ in the amine group. The out of plane bending mode of this group is probably responsible for the band located at $1640 \mathrm{~cm}^{-1}$. The $(\mathrm{C}-\mathrm{H})$ stretching of methylene group is centered on $2925 \mathrm{~cm}^{-1}$.

The band around $1389 \mathrm{~cm}^{-1}$ is probably the result of the bending vibration of $(\mathrm{C}-\mathrm{H})$ and the stretching of $(\mathrm{C}-\mathrm{C})$. The stretching modes of $(\mathrm{C}-\mathrm{N})$ are probably observed around $1114 \mathrm{~cm}^{-1}$.

3.5. Thermal Properties. The differential scanning calorimetry (DSC) thermogram, shown in Figure 6 was performed with a DSC EVO131 instrument under nitrogen atmosphere. Firstly, no phase transition was observed when the sample was under cooling until $-45^{\circ} \mathrm{C}$; then, during heating from -45 to $20^{\circ} \mathrm{C}$, we observed an energetic effect that reveals a phase transition in the temperature range of $(-17 /-12)^{\circ} \mathrm{C}$ accompanied by a significant enthalpy transition $(\Delta H)$ evaluated at $2.732 \mathrm{Jg}^{-1}$. Comparing the heating and the cooling curves, the observed phenomenon seems to be irreversible. Further treatments are scheduled to know the structural behaviour of the resulting compound after the DSC experiment.

3.6. X-Ray Powder Diffraction. The X-ray powder diffraction technique (XRD) was used to control the crystalline phase purity. The diffraction pattern was obtained on a D8 ADVANCE Bruker diffractometer with a Lynxeye accelerator using $\mathrm{Cu}\left(\mathrm{K} \alpha_{1} / \alpha_{2}=1.54060 / 1.54439 \AA\right)$ wavelength. The measurement was performed in spinning mode $\left(60 \mathrm{tr} \cdot \mathrm{mn}^{-1}\right)$ in order to minimize the preferential orientation effect of the crystallites with step-scanning $\left(\Delta 2 \theta=0.02^{\circ}\right)$ constant time 


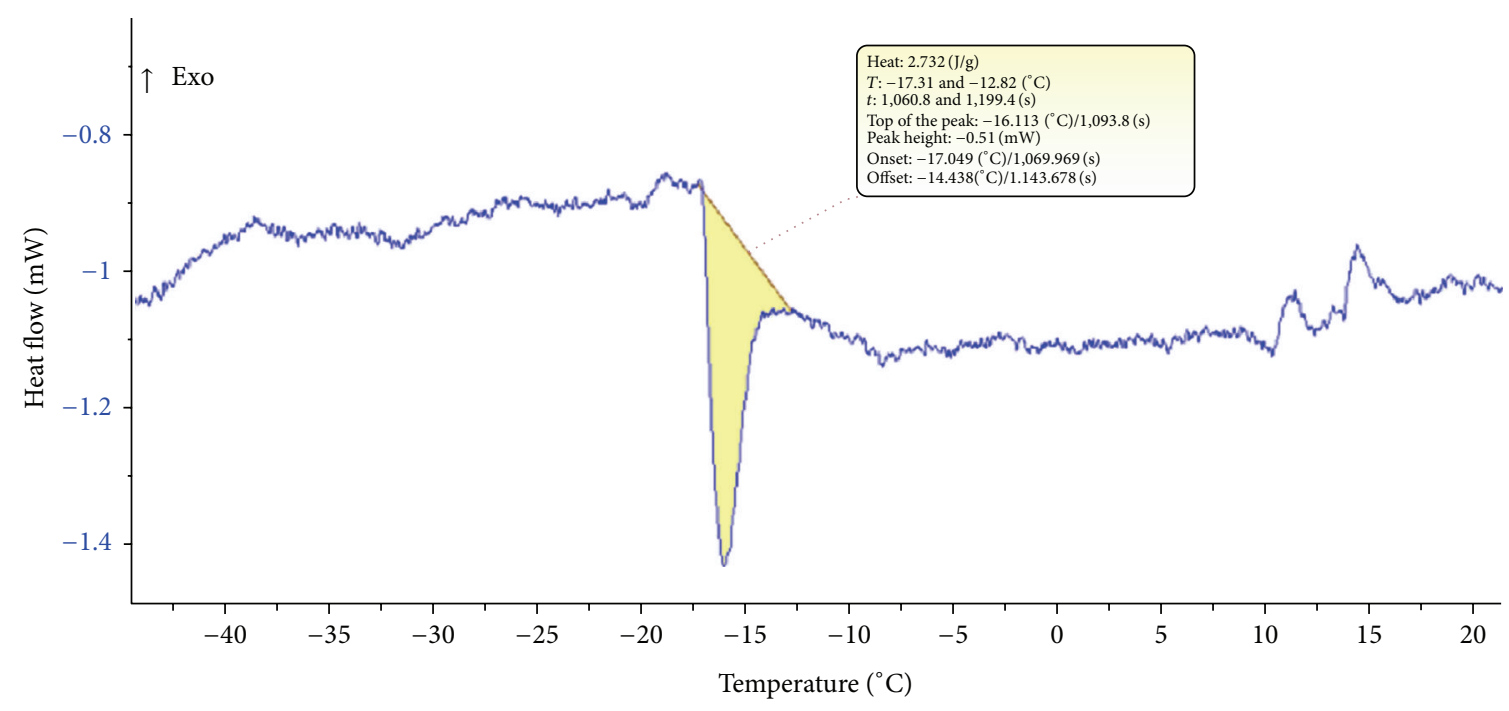

(a)

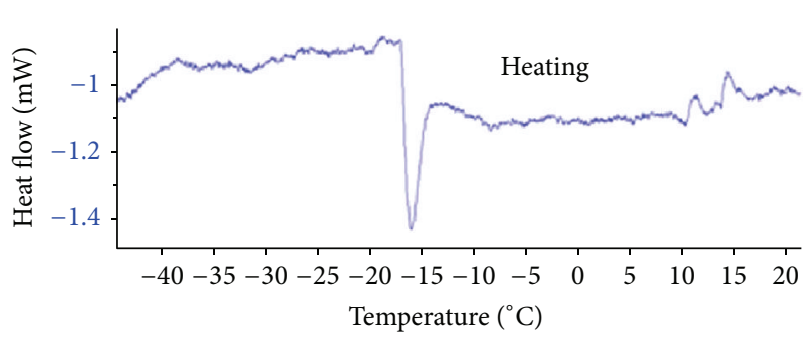

(b)

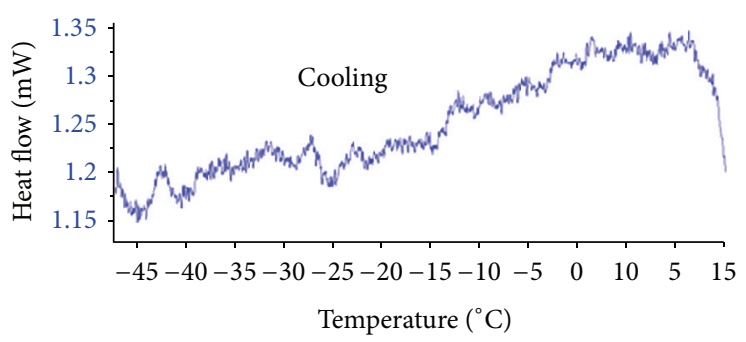

(c)

FIGURE 6: Differential scanning calorimetry curves of $\mathrm{C}_{10} \mathrm{H}_{28} \mathrm{~N}_{4} \mathrm{Bi}_{2} \mathrm{Br}_{10}$.

interval of $0.1 \mathrm{~s}$. The quantitative criteria of goodness of fits are the following agreement $\mathrm{R}$ factors:

$$
\begin{gathered}
\mathrm{R} p=\frac{\sum\left|Y_{i} \cdot(\mathrm{obs})-(1 / \mathrm{c}) Y_{i}(\mathrm{cal})\right|}{\sum Y_{i} \cdot(\mathrm{obs})}, \\
\mathrm{R} w p=\sqrt{\frac{\sum w_{i}\left[Y_{i} \cdot(\mathrm{obs})-(1 / c) Y_{i} \cdot(\mathrm{cal})\right]^{2}}{w_{i}\left[Y_{i} \cdot(\mathrm{obs})\right]^{2}}}, \\
\mathrm{GOF}=\sqrt{\frac{\sum w_{i}\left[Y_{i} \cdot(\mathrm{obs})-(1 / c) Y_{i} \cdot(\mathrm{cal})\right]^{2}}{N-p}},
\end{gathered}
$$

where $Y_{i}(\mathrm{obs})$ and $Y_{i}(\mathrm{cal})$ are the observed and calculated intensities at the ith step in the pattern, respectively. $w_{i}$ is the reciprocal of the variance of each observation; the summation is carried out over all the observations and " $c$ " is a scale factor. [15].

The refinements were carried out using TOPAS program

The basic structural model for the $\mathrm{C}_{10} \mathrm{H}_{28} \mathrm{~N}_{4} \mathrm{Bi}_{2} \mathrm{Br}_{10}$ was taken from Topa et al. output [16]. Details of the refinement are given in Table 5 .

Figure 7 shows good agreement between the observed and calculated XRD patterns which confirms the crystalline purity of the prepared compound with an experimental error of $3 \%$ of mass. Furthermore, the XRPD raw diffraction is
TABLE 5: Unit cell parameters and details of Rietveld refinement of $\mathrm{C}_{10} \mathrm{H}_{28} \mathrm{~N}_{4} \mathrm{Bi}_{2} \mathrm{Br}_{10}$.

\begin{tabular}{lc}
\hline Formula & $\mathrm{C}_{10} \mathrm{H}_{28} \mathrm{~N}_{4} \mathrm{Bi}_{2} \mathrm{Br}_{10}$ \\
System & Monoclinic \\
Space group & $\mathrm{P} 2_{1} / \mathrm{c}$ \\
$Z$ & 4 \\
Unit cell & \\
$\quad a / \AA$ & $11.387(1)$ \\
$\quad b / \AA$ & $11.260(1)$ \\
$c / \AA$ & $12.577(1)$ \\
$\beta /\left(^{\circ}\right)$ & $115.925(3)$ \\
Volume/ $/ \AA^{3}$ & $1450.45(2)$ \\
Density & $3.245(5)$ \\
Zero point $2 \theta /\left(^{\circ}\right)$ & $0.0182(8)$ \\
Reliability factors $(\%)$ & \\
R $p$ & 3.85 \\
R $w p$ & 5.89 \\
$\mathrm{R}_{B}$ & 4.917 \\
$\mathrm{R}_{F}$ & 2.22 \\
\hline
\end{tabular}

marked with the presence of a large hump centered around $2 \theta=13^{\circ}$, signature of an amorphous part. The TOPAS degree of crystallinity calculation gives about $86 \%$. 


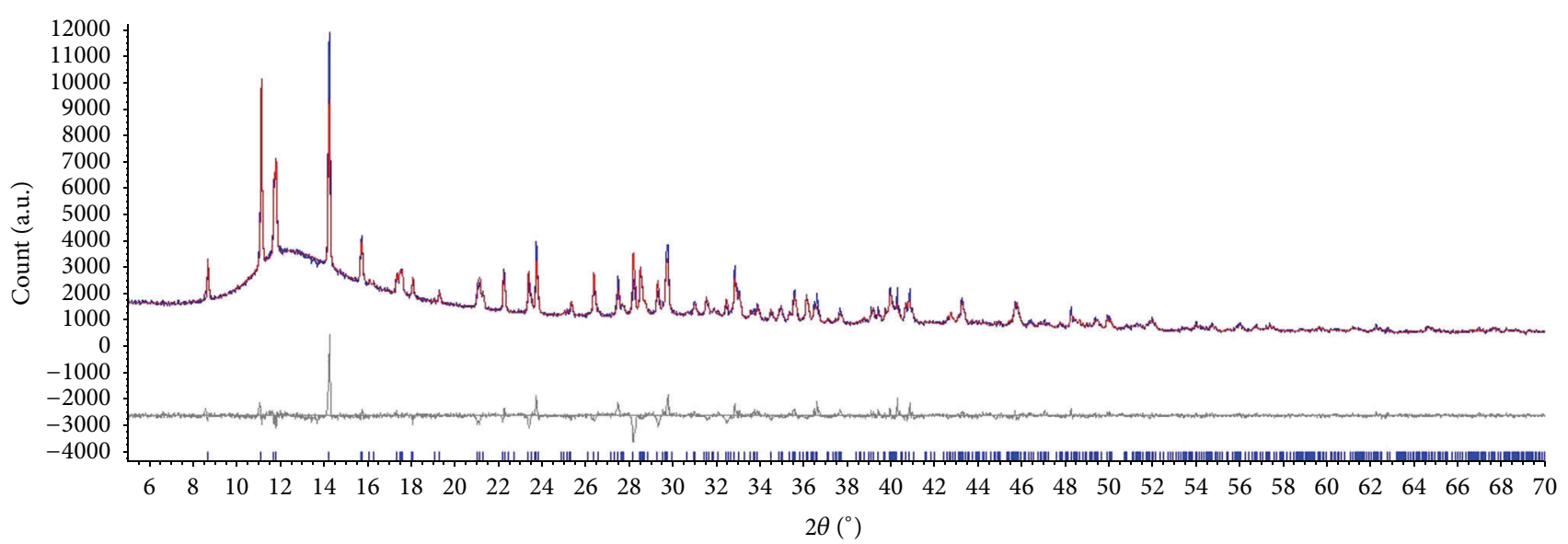

FIGURE 7: Experimental and calculated X-ray diffraction patterns and their difference for $\mathrm{C}_{10} \mathrm{H}_{28} \mathrm{~N}_{4} \mathrm{Bi}_{2} \mathrm{Br}_{10}$.
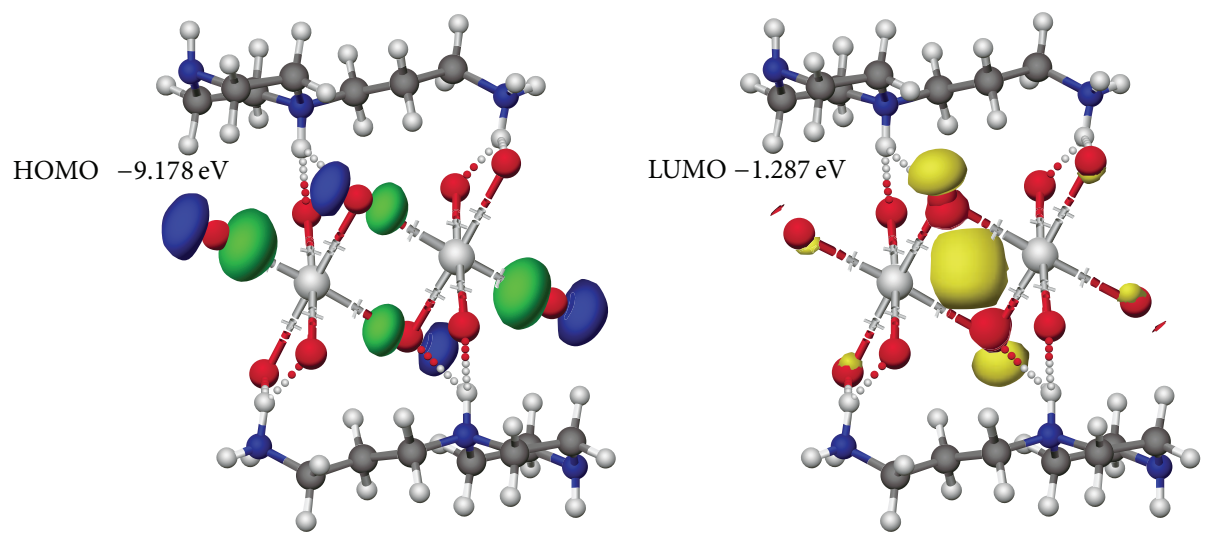

FIGURE 8: Calculated frontier molecular orbital of the title compound.

3.7. The HOMO-LUMO Gap. Crystalline materials can be classified according to their band gap. The $\mathrm{C}_{10} \mathrm{H}_{28} \mathrm{~N}_{4} \mathrm{Bi}_{2} \mathrm{Br}_{10}$ exhibits absorption bands around $(-1,287)-(-9,179)=$ $7,891 \mathrm{eV}$ calculated by the program "CAChe" using the semiempirical PM3 method and corresponding to the electronic transition from the highest occupied molecular orbital (HOMO) to the lowest unoccupied one (LUMO). The atomic orbital compositions of the frontier molecular orbital are sketched in Figure 8.

We can note the HOMO contribution coming from the halogen. In the LUMO, the percentage of contribution from the bromine atoms is dominant. These calculations show that the electronic properties are roughly imposed by the inorganic part. The Bi coordination geometry is the dominant structural factor influencing the electronic structure of studied compound [17].

\section{Conclusion}

The present paper has shown that the new organicinorganic hybrid $\mathrm{C}_{10} \mathrm{H}_{28} \mathrm{~N}_{4} \mathrm{Bi}_{2} \mathrm{Br}_{10}$ was synthesized by slow evaporation. Its structure is built up by dibutylpyrazinium dications and discrete (0-D) bromobismuthate anions. Several experimental techniques have been used to characterize the new compound.

The crystal structure was solved by single crystal X-ray diffraction. The vibrational properties were studied by Raman scattering and infrared spectroscopy; the crystal morphology was carries out using the Bravais-Freidel and Donnay-Harker model, and the X-ray powder diffraction measurement was carried out to check the title compound's purity.

The crystal structure of $\mathrm{C}_{10} \mathrm{H}_{28} \mathrm{~N}_{4} \mathrm{Bi}_{2} \mathrm{Br}_{10}$ consists of discrete $\left[\mathrm{Bi}_{2} \mathrm{Br}_{10}\right]^{4-}$ anions with dinuclear geometry of two $\mathrm{BiBr}_{6}$ octahedra sharing two bridging $\mathrm{Br}$ atoms and $\left[\mathrm{C}_{10} \mathrm{H}_{28} \mathrm{~N}_{4}\right]^{4+}$. The cohesion is assumed by hydrogen bonds. The title compound undergoes one low-temperature phase transitions at $-17^{\circ} \mathrm{C}$ identified by differential scanning calorimetry.

\section{Conflict of Interests}

The authors declare that there is no conflict of interests regarding the publication of this paper. 


\section{References}

[1] A. Piecha, V. Kinzhybalo, R. Jakubas, J. Baran, and W. Medycki, "Structural characterization, molecular dynamics, dielectric and spectroscopic properties of tetrakis(pyrazolium) bis $\left(\mu_{2}-\right.$ bromo-tetrabromobismuthate(III)) dihydrate, $\left[\mathrm{C}_{3} \mathrm{~N}_{2} \mathrm{H}_{5}\right]_{4}$. $\left[\mathrm{Bi}_{2} \mathrm{Br}_{10}\right] \cdot 2 \mathrm{H}_{2} \mathrm{O}$," Journal of Coordination Chemistry, vol. 9, pp. 1036-1048, 2007.

[2] G. A. Bowmaker, P. C. Junk, M. Lee Aaron, B. W. Skelton, and A. H. White, "Synthetic, structural and vibrational spectroscopic studies in bismuth(III) halide/ $N, N^{\prime}$-Aromatic bidentate base systems. I large-cation $\left(2,2^{\prime}\right.$-bipyridinium and 1,10-phenanthrolinium) salts of polyhalobismuthate (III) ions," Australian Journal of Chemistry, vol. 51, no. 4, pp. 293-309, 1998.

[3] F. Benetollo, G. Bombieri, G. Alonzo, N. Bertazzi, and G. A. Casella, "Synthesis and crystal structure of $\left[(\mathrm{PhenH})\left(\mathrm{PhenH}_{2}\right)\right]$. $\left[\mathrm{BiCl}_{6}\right] \cdot 2 \mathrm{H}_{2} \mathrm{O}$ with different o-phenanthroline protonations," Journal of Chemical Crystallography, vol. 28, no. 11, pp. 791-796, 1998.

[4] G. Alonzo, F. Benetollo, N. Bertazzi, and G. Bombieri, "Synthesis and crystal structures of $4,4^{\prime}$-bipyridinium and $2,2^{\prime}$ bipyridinium pentachloro complexes containing the polynuclear anions [Bi2Cl10]4- and [Bi4Cl20]8-," Journal of Chemical Crystallography, vol. 29, no. 8, pp. 913-919, 1999.

[5] G. M. Sheldrick, SHELXS-97, Program for Crystal Structure Solution, University of Göttingen, Göttingen, Germany, 1997.

[6] G. Sheldrick M, SHELXL-97: Program for the Refinement of Crystal Structures, University of Göttingen, Göttingen, Germany, 1997.

[7] K. Brandenburg, Diamond, Crystal Impact GbR, Bonn, Germany, 2008.

[8] A. Bravais, Etudes Cristallographiques, Gauthier-Villars, Paris, France, 1913.

[9] G. Fridel, "Crystal habits of minerals," Bulletin de la Société Chimique de France, pp. 326-455, 1907.

[10] J. D. Donnay and H. Harker D, Springer Handbook of Crystal Growth, American Mineralogist, 1937.

[11] (CCDC), Mercury CSD 3. 0. 1 (Build RC6), Cambridge Crystallographic Data Centre (CCDC), 2011.

[12] L. Pauling, The Nature of Chemical Bond, Cornell University Press, Ithaca, NY, USA, 1960.

[13] R. D. Shannon, "Revised effective ionic radii and systematic studies of interatomic distances in halides and chalcogenides," Acta Crystallographica A, vol. 32, part 5, pp. 751-767, 1976.

[14] Cache: Worksystem 7.5.0.85, Fujitsu Limited, Oxford, UK, 20002006.

[15] A. A. Coelho, TOPAS, Version 4.2 (Computer Software), Coelho Software, Brisbane, Australia, 2009.

[16] D. Topa, E. Makovicky, H. J. Schimper et al., "The crystal structure of SnSb4S7, A new member of the meneghinite homologous series," Canadian Mineralogist, vol. 48, no. 5, pp. 1119-1126, 2010.

[17] J. E. Monat, J. H. Rodriguez, and J. K. McCusker, "Ground- and excited-state electronic structures of the solar cell sensitizer bis $\left(4,4^{\prime}\right.$-dicarboxylato- $2,2^{\prime}$-bipyridine)bis(isothiocyanato)ruthenium(II)," Journal of Physical Chemistry A, vol. 106, no. 32, pp. 7399-7406, 2002. 

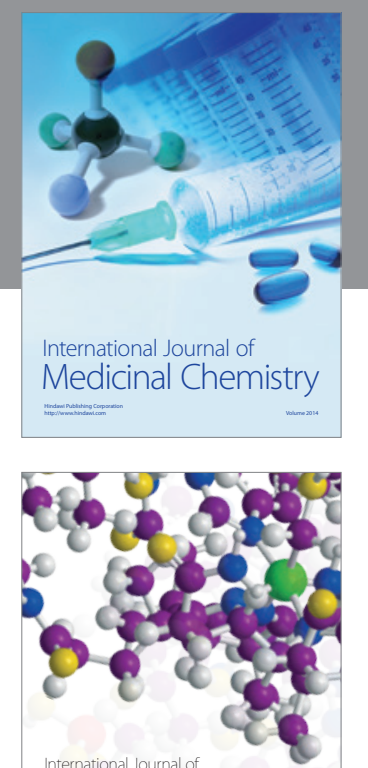

\section{Carbohydrate} Chemistry

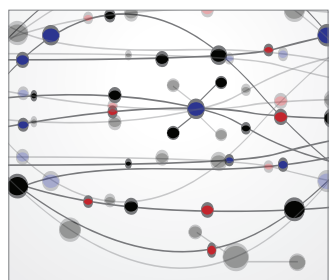

The Scientific World Journal
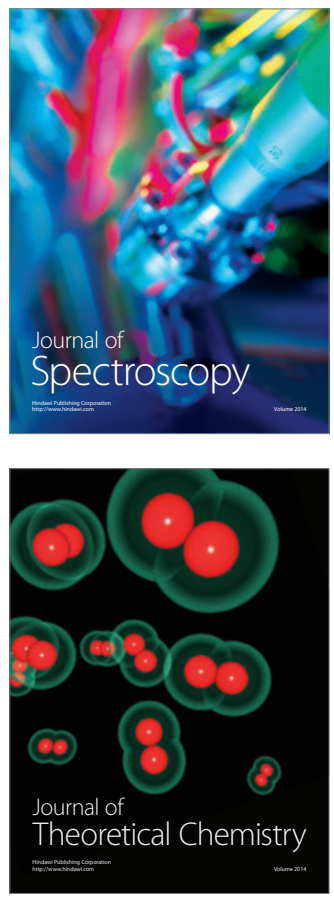
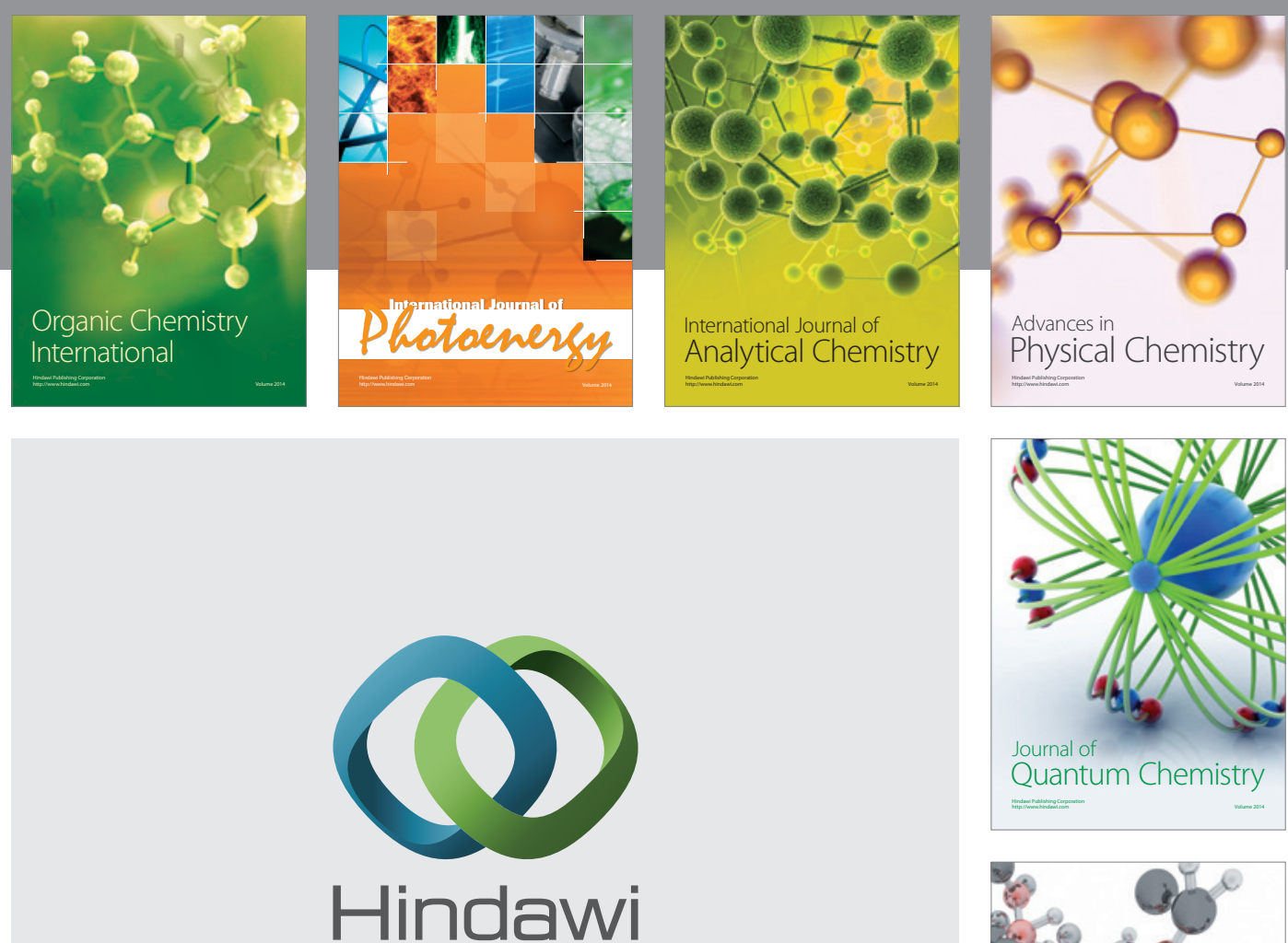

Submit your manuscripts at

http://www.hindawi.com

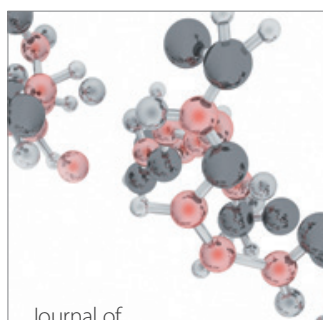

Analytical Methods

in Chemistry

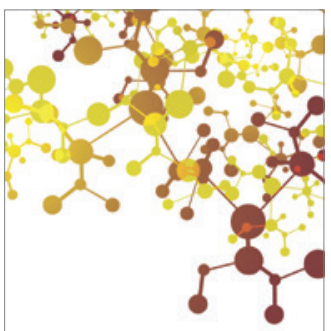

Journal of

Applied Chemistry

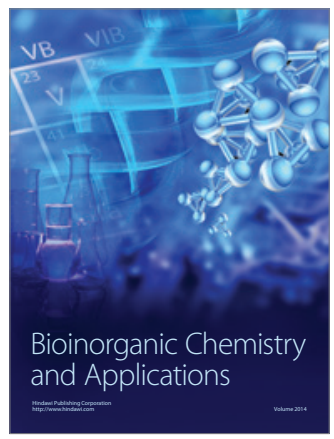

Inorganic Chemistry
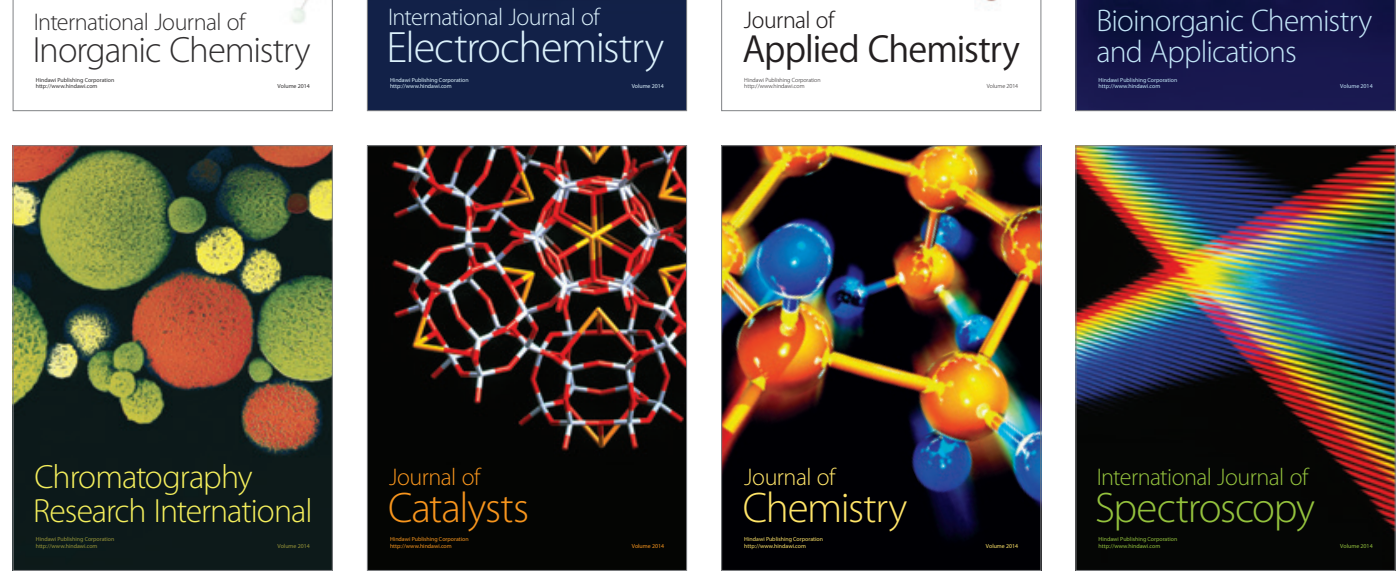